\title{
Proceedings
}

\section{Genotyping of Cryptosporidium spp. from a Sewage-Contaminated River in Guilan, Iran ${ }^{\dagger}$}

\author{
Mahmoudi MR 1,2,* and Karanis P 3,4,* \\ 1 Department of Parasitology, Faculty of Medicine, Guilan University of Medical Sciences, P.O. Box 3363., \\ Rasht, Iran \\ 2 Medical Biotechnology Research Center, Guilan University of Medical Sciences, P.O. Box 3363., Rasht, Iran \\ 3 The University of Cologne, Medical Faculty and University Hospital, P.O. Box 50931., Cologne, Germany \\ 4 Department of Basic and Clinical Sciences, University of Nicosia Medical School, P.O. Box. 24005., Nicosia, \\ Cyprus \\ * Correspondence: mrmahmoodi2002@yahoo.com (M.M.R.); karanis.p@unic.ac.cy (K.P.); Tel.: +981333690921 \\ $\&+981333690884$ (ext. 231) (M.M.R.); +357-22471813 (K.P.) \\ + Presented at the 4th EWaS International Conference: Valuing the Water, Carbon, Ecological Footprints of \\ Human Activities, Online, 24-27 June 2020.
}

Published: 9 August 2020

\begin{abstract}
The role of water in Cryptosporidium transmission is now well recognized. In the present study, 19 water samples were collected from the river contaminated with wastewater in Guilan, Iran. This province lies along the Caspian Sea and has a Mediterranean-like climate. The species of Cryptosporidium were identified by polymerase chain reaction (PCR) assay using two set primers: (CPB-DIAGF/R and N-DIAGF2/R2) and (Xiao F1/R1 and F2/R2). A total of 10/19 water samples were positive for Cryptosporidium species (C. parvum, C. muris and C. hominis). The use of sewage-contaminated river water for the irrigation of agriculture farms is a threat of infection to the local population.
\end{abstract}

Keywords: Cryptosporidium; water; PCR; Iran

\section{Introduction}

Recent molecular studies of cryptosporidiosis in animals and the environment helped researchers to better understand the transmission of cryptosporidiosis in humans and the public health significance of Cryptosporidium spp. [1]. Waterborne cryptosporidiosis has been reported worldwide, and the ingestion of oocyst-contaminated drinking water has led to a large number of outbreaks, mainly reported from North America, the United Kingdom, Japan, and Australia [2-4]. The use of molecular techniques in epidemiological studies has shown that five Cryptosporidium species (C. hominis, C. parvum, C. meleagridis, C. felis, and C. canis) are responsible for most human infections and two species, C. parvum and C. hominis, are the most common [5]. The distribution of Cryptosporidium species in environmental water and wastewater in Iran is unclear. The objective of this study was to identify the genotype of Cryptosporidium spp. in two important rivers in Iran.

\section{Materials and Methods}

\subsection{Geography and Sample Collection}

Guilan Province $\left(37.2809^{\circ} \mathrm{N}, 49.5924^{\circ} \mathrm{E}\right)$ lies along the Caspian Sea and has a moderate, mild, and Mediterranean-like climate. Goharrood river is a branch of the Sefidrood River that crosses Rasht City and finally meets the Bandar-e Anzali Lagoon. In the present study, 19 water samples were collected from the Goharrood River. Many pollutants, such as rural, urban, and agricultural runoff and animals' raw sewage threaten water supplies in the cities of Guilan [6]. About $5 \mathrm{~L}$ of each 
sample was filtered through a cellulose nitrate filter of pore size $1.2 \mu \mathrm{m}$ using a vacuum pump. The sediment pellet was subjected to sucrose flotation [7], then the supernatant was subject to DNA extraction and Polymerase Chain Reaction (PCR).

\subsection{DNA Extraction and PCR}

DNA was extracted using the QIAamp DNA mini kit (Qiagen GmbH, Hilden, Germany) according to the manufacturer's instructions with some modifications. Briefly, the suspension, including amoeba cysts or trophozoites, was frozen and thawed at $-196{ }^{\circ} \mathrm{C}$ for $5 \mathrm{~min}$ ten times, followed by $5 \mathrm{~min}$ in boil water [8]. Two primer sets were used in this study. The first was a genus-specific primer targeting the 18 rRNA gene-specifically for Cryptosporidium spp.-used for the amplification of the approximately $435 \mathrm{bp}$ fragment using CPB-DIAGF/R and N-DIAGF2/R2 primers $[9,10]$.

The second set, XIAOF1/R1 and XIAO F2/R2, were used to amplify the approximately $850 \mathrm{bp}$ fragment of the gene encoding the 18SSU rRNA of the genus Cryptosporidium as described previously [11,12]. Each reaction was performed in $50 \mu \mathrm{L}$ and both PCR reactions were performed in PCR tubes according to a previous study [9-12]. The PCR products electrophoresis was performed on $1.5 \%$ gel agarose stained with ethidium bromide solution and visualized under UV light. The PCR products were then sequenced and all sequences data were manually edited and analyzed with reference sequences using the Chromas software program. Genotype identification was performed by the available Cryptosporidium DNA sequences in GenBank.

\section{Results}

In the present study, 10/19 of the samples were positive for Cryptosporidium spp. two nested PCR primers. DNA sequencing of five PCR products revealed the presence of three species of Cryptosporidium, C. parvum (3), C. muris (1) and C. hominis (1), respectively. C. paroum was the most common species.

\section{Discussion}

The detection of pathogens and the safety of drinking water are topics of great concern to health authorities. Accurate identification of Cryptosporidium species requires the use of genotyping tools. Currently, most Cryptosporidium genotyping tools use PCR targeting the small subunit (SSU) rRNA gene [13]. Molecular studies have shown that five Cryptosporidium species (C. hominis, C. parvum, C. meleagridis, C. felis, and C. canis) are responsible for most human infections, but two species - C. hominis and C. parvum - are the most common, and the role of water in disease transmission is now well recognized [5]. Numerous outbreaks of human cryptosporidiosis all over the world have been reported, mainly from North America, the United Kingdom, Japan, and Australia [2-4,14]. In the present study, C. parvum, C. muris and C. hominis were detected. The occurrence of species other than C. parvum in the environment is well recognized. Xiao et al. $[15,16]$ reported the presence of Cryptosporidium spp. in 27 of 29 storm water samples in the United States, mainly wildlife Cryptosporidium genotypes. In contrast, the most common species found in surface waters were $C$. parvum, C. hominis, and C. andersoni, with the last reported to be the most commonly found in wastewater (eight samples). Mahmoudi et al. [11,12] analyzed surface and river water samples in Iran by different methods, and showed that $C$. parvum was the most prevalent species, followed by C. hominis and C. canis, respectively [11,12]. Another study [17] reported this parasite from untreated water samples in Iran. In a comprehensive study by Keshavarz et al. (2009), Iranian cattle were mainly found to be infected with C. parvum (72.6\%), C. andersoni (17.7\%), and C. bovis (7.8\%) [18]. C. parvum was the predominant species in children with diarrhea and AIDS patients in other studies in Iran $[19,20]$. Other studies in Iran have shown a frequent occurrence of $C$. hominis in children or AIDS patients [21,22]. C. muris was detected in the present study, which is a well-known rodent parasite [23]; the results of the present study indicate that these animals are also a source of Cryptosporidium oocysts in river water in Iran. The differences in the distribution of Cryptosporidium 
species in humans are considered an indication of differences in infection sources [1]. C. hominis is responsible for far more infections than C. parvum in humans in developing countries, where genotyping studies have been conducted [24-29]. In the United Kingdom, Europe, and New Zealand, C. parvum was as common as C. hominis in humans [30-34]. The results of the present study indicate that the investigated river water supplies were contaminated by pathogenic species of Cryptosporidium from humans and animals.

\section{Conclusions}

The use of long-term sewage-contaminated river water for the irrigation of crops and agriculture farms and their subsequent transfer to the food chain is a threat of infection to the population. More future studies with a systematic sampling of water in the study area would provide a better picture of the extent of water contamination with Cryptosporidium species. Periodic determination of Cryptosporidium spp. in river water can help to develop strategies for the protection of human health.

Author Contributions: All authors have read and agree to the published version of the manuscript. M.M.R.: Acquisition of data, technical and material support. M.M.R. and K.P.: Analysis and interpretation of data, drafting of the manuscript and critical revision of the manuscript for important intellectual content. All authors have read and agree to the published version of the manuscript.

Funding: This work supported by Guilan University of Medical Sciences, Rasht, Iran. (Grant Number: 93121113).

Conflicts of Interest: The authors declare no conflict of interest.

\section{References}

1. Feng, Y.; Li, N.; Duan, L.; Xiao, L. Cryptosporidium genotype and subtype distribution in raw wastewater in Shanghai, China: Evidence for possible unique Cryptosporidium hominis transmission. J. Clin. Microb. 2009, 47, 153-157.

2. Zhou, L.; Singh, A.; Jiang, J.; Xiao, L. Molecular surveillance of Cryptosporidium spp. in raw wastewater in Milwaukee: Implications for understanding outbreak occurrence and transmission dynamics. J. Clin. Microb. 2003, 4, 5254-5257.

3. Karanis, P.; Kourenti, C.; Smith, H. Waterborne transmission of protozoan parasites: A worldwide review of outbreaks and lessons learnt. J. Wat. Health 2007, 5, 1-38.

4. Baldursson, S.; Karanis, P. Waterborne transmission of protozoan parasites: Review of worldwide outbreaks-An update 2004-2010. Wat. Res. 2011, 45, 6603-6614.

5. Plutzer, J.; Karanis, P.; Domokos, K.; Törökné, A.; Márialigeti, K. Detection and characterisation of Giardia and Cryptosporidium in Hungarian raw, surface and sewagewater samples by IFT, PCR and sequence analysis of the SSUrRNA and GDH genes. Int. J. Hyg. Environ. Health 2008, 211, 524-533.

6. Mahmoudi, M.R.; Kazemi, B.; Haghighi, A.; Karanis, P. Detection of Acanthamoeba and Toxoplasma in river water samples by mlecular methods in Iran. Iran. J. Parasitol. 2015, 10, 250-257.

7. Mahmoudi, M.; Ashrafi, K.; Abedinzadeh, H.; Tahvildar-Bideruni, F.; Haghighi, A.; Bandehpour, M.; Tghipour, N.; Kazemi, B. Development of sensitive detection of Cryptosporidium and Giardia from surface water in iran. Iran. J. Parasitol. 2011, 6, 43-51.

8. Jiang, J.; Alderisio, K.A.; Xiao, L. Distribution of Cryptosporidium genotypes in storm event water samples from three watersheds in New York. Appl. Environ. Microb. 2005, 71, 4446-4454.

9. Nichols, R.A.B.; Campbell, B.M.; Smith, H.V. Identification of Cryptosporidium spp. oocysts in U.K. still natural mineral waters and drinking waters using a modified nested PCR-RFLP assay. Appl. Environ. Microb. 2003, 69, 4183-4189.

10. Gallas-Lindemann, C.; Sotiriadou, S.; Plutzer, J.; Noack, M.J.; Mahmoudi, M.R.; Karanis, P. Giardia and Cryptosporidium spp. dissemination during wastewater treatment and comparative detection via immunofluorescence assay (IFA), nested polymerase chain reaction (nested PCR) and loop mediated isothermal amplification (LAMP). Acta Trop. 2016, 158, 43-51. 
11. Mahmoudi, M.R.; Kazemi, B.; Mohammadiha, A.; Mirzaei, A.; Karanis, P. Detection of Cryptosporidium and Giardia (oo)cysts by IFA, PCR and LAMP in surface water from Rasht, Iran. Trans. R. Soc. Trop. Med. Hyg. 2013, 107, 511-517.

12. Mahmoudi, M.R.; Nazemalhosseini-Mojarad, E.; Kazemi, B.; Haghighi, A.; Mirzaei, A.; Mohammadiha, A.; Jahantab, S.; Xiao, L.; Karanis, P. Cryptosporidium genotypes and subtypes distribution in river water in Iran. J. Wat. Health 2015, 13, 600-606.

13. Xiao, L.; Feng, Y. Molecular epidemiologic tools for waterborne pathogens Cryptosporidium spp. and Giardia duodenalis. Food Waterborne Parasitol. 2017, 8, 14-32.

14. Mahmoudi, M.R.; Ongerth, J.E.; Karanis, P. Cryptosporidium and cryptosporidiosis: The Asian perspective. Int. J. Hyg. Environ. Health 2017, 220, 1098-1109.

15. Xiao, L.; Singh, A.; Limor, J.; Graczyk, T.K.; Gradus, S.; Lal, A.A. Molecular characterization of Cryptosporidium oocysts in samples of raw surface water and wastewater. Appl. Environ. Microb. 2001, 67, 1097-1101.

16. Xiao, L.; Alderisio, K.; Limor, J.; Royer, M.; Lal, A.A. Identification of species and sources of Cryptosporidium oocysts in storm waters with a small-subunit rRNA-based diagnostic and genotyping tool. Appl. Environ. Microb. 2000, 66, 5492-5498.

17. Naeini, K.M.; Asadi, M.; Chaleshtori, M.H. Detection and molecular characterization of Cryptosporidium species in recreational waters of Chaharmahal va Bakhtiyari province of Iran using nested PCR-RFLP. Iran. J. Parasitol. 2001, 6, 20-27.

18. Keshavarz, A.; Haghighi, A.; Athari, A.; Kazemi, B.; Abadi, A.; Nazemalhosseini-Mojarad, E. Prevalence and molecular characterization of bovine Cryptosporidium in Qazvin province, Iran. Vet. Parasitol. 2009, 160, 316-318.

19. Keshavarz, A.; Athari, A.; Haghighi, A.; Kazami, B.; Abadi, A.; Nazemalhosseini-Mojarad, E.; Kashi, L. Genetic characterization of Cryptosporidium spp. among children with diarrhea in Tehran and Qazvin provinces, Iran. Iran. J. Parasitol. 2008, 3, 30-36.

20. Meamar, A.R.; Rezaian, M.; Rezaie, S.; Mohraz, M.; Mohebali, M.; Mohammad, K.; Golestan, B.; Guyot, K.; Dei-Cas, E. SSU-rRNA gene analysis of Cryptosporidium spp. in HIV positive and negative patients. Iran J. Publ. Health 2006, 35, 1-7.

21. Pirestani, M.; Sadraei, J.; Zavvar, M.; Vaeznia, H. Molecular characterization of Cryptosporidium isolates from human and bovine using 18 rRNA gene in Shahriar county of Tehran, Iran. Parasitol. Res. 2008, 103, 467-472.

22. Zavvar, M.; Sadraei, J.; Emadi, H.; Pirestani, M. The use of a nested PCR-RFLP technique, based on the parasite's $18 \mathrm{~S}$ ribosomal RNA, to characterize Cryptosporidium isolates from HIV/AIDS patients. Ann. Trop. Med. Parasitol. 2008, 102, 597-601.

23. Chalmers, R.M.; Sturdee, A.P.; Bull,S.A.; Miller, A.; Wright, S.E. The prevalence of Cryptosporidium parvum and C. muris in Mus domesticus, Apodemus sylvaticus and Clethrionomys glareolus in an agricultural system. Parasitol. Res. 1997, 83, 478-482.

24. Bushen, O.Y.; Kohli, A.; Pinkerton, R.; Dupnik, K.; Newman, R.D.; Sears, C.L.; Fayer, R.; Lima, A.A.; Guerrant, R.L. Heavy cryptosporidial infections in children in northeast Brazil: Comparison of Cryptosporidium hominis and Cryptosporidium parvum. Trans. R. Soc. Trop. Med. Hyg. 2007, 101, 378-384.

25. Das, P.; Roy, S.S.; MitraDhar, K.; Dutta, P.; Bhattacharya, M.K.; Sen, A.; Ganguly, S.; Bhattacharya, S.; Lal, A.A.; Xiao, L. Molecular characterization of Cryptosporidium spp. from children in Kolkata, India. J. Clin. Microb. 2006, 44, 4246-4249.

26. Gatei, W.; Greensill, J.; Ashford, R.W.; Cuevas, L.E.; Parry, M.C.; Cunliffe, N.A.; Beeching, N.J.; Hart, C.A. Molecular analysis of the 18S rRNA gene of Cryptosporidium parasites from patients with or without human immunodeficiency virus infections living in Kenya, Malawi, Brazil, the United Kingdom, and Vietnam. J. Clin. Microb. 2003, 4, 1458-1462.

27. Gatei, W.; Wamae, C.N.; Mbae, C.; Waruru, A.; Mulinge, E.; Waithera, T.; Gatika, S.; Kamwati, S.; Revathi, G.; Hart, C.A. Cryptosporidiosis: Prevalence, genotype analysis, and symptoms associated with infections in children in Kenya. Am. J. Trop. Med. Hyg. 2006, 75, 78-82.

28. Muthusamy, D.; Rao, S.S.; Ramani, S.; Monica, B.; Banerjee, I.; Abraham, O.C.; Mathai, D.C.; Primrose, B.; Muliyil, J.; Wanke, C.A.; et al. Multilocus genotyping of Cryptosporidium sp. isolates from human immunodeficiency virus-infected individuals in South India. J. Clin. Microb. 2006, 44, 632-634. 
29. Tumwine, J.K.; Kekitiinwa, A.; Bakeera-Kitaka, S.; Ndeezi, G.; Downing, R.; Feng, X.; Akiyoshi, D.E.; Tzipori, S. Cryptosporidiosis and microsporidiosis in Ugandan children with persistent diarrhea with and without concurrent infection with the human immunodeficiency virus. Am. J. Trop. Med. Hyg. 2005, 73, 921-925.

30. Alves, M.; Xiao, L.; Sulaiman, I.; Lal, A.A.; Matos, O.; Antunes, F. Subgenotype analysis of Cryptosporidium isolates from humans, cattle, and zoo ruminants in Portugal. J. Clin. Microb. 2003, 41, 2744-2747.

31. Fretz, R.; Svoboda, P.; Ryan, U.M.; Thompson, R.C.; Tanners, M.; Baumgartner, A. Genotyping of Cryptosporidium spp. isolated from human stool samples in Switzerland. Epidemiol. Infect. 2003, 131, 663-667.

32. Guyot, K.; Follet-Dumoulin, A.; Lelievre, E.; Sarfati, C.; Rabodonirina, M.; Nevez, G.; Cailliez, J.C.; Camus, D.; Dei-Cas, E. Molecular characterization of Cryptosporidium isolates obtained from humans in France. J. Clin. Microb. 2001, 39, 3472-3480.

33. Learmonth, J.J.; Ionas, G.; Ebbett, K.A.; Kwan, E.S. Genetic characterization and transmission cycles of Cryptosporidium species isolated from humans in New Zealand. Appl. Environ. Microb. 2004, 70, 3973-3978.

34. Leoni, F.; Amar, C.; Nichols, G.; Pedraza-Diaz, S.; McLauchlin, J. Genetic analysis of Cryptosporidium from 2414 humans with diarrhoea in England between 1985 and 2000. J. Med. Microb. 2006, 55, 703-707.

(C) 2020 by the authors. Licensee MDPI, Basel, Switzerland. This article is an open access article distributed under the terms and conditions of the Creative Commons Attribution (CC BY) license (http://creativecommons.org/licenses/by/4.0/). 